\title{
On the Boron Content of the Shallow-Water Deposits*
}

\author{
Yoshikazu YАмамото**
}

\begin{abstract}
The Abundance of boron was studied in the shallow-water deposits from Nanao Bay, Ishikawa Prefecture, and further in order to find the relation of boron content to depth and coastal geology, the deposits taken in Kasaoka Bay, Okayama Prefecture, at Oki Island, Shimane Prefecture and at the several small islands around Honshu, Japan were analysed.

The boron contents Nanao Bay deposits ranged from 16 to $103 \mathrm{ppm}$ and the average was $67 \pm 20 \mathrm{ppm}$. The born content in the deposits of North Bay of Nanao which is affected by the open sea (av. $56 \pm 12 \mathrm{ppm}$ ), is considerably lower than that in those in South Bay of Nanao which is subjected to slight influence of the open sea (av. $90 \pm 9 \mathrm{ppm}$ ). The boron contents of the deposits increase with the increase in the contents of organic matter. There are positive correlations between the contents of boron and those of sulfur, organic carbon, nitrogen and vanadium.

The abundance values of boron in the samples collected in Kasaoka Bay and at Oki showed the range of $16-29$ and $28-40 \mathrm{ppm}$ respectively, but the result is insufficient to prove a definite relation with the depth.

The deposits collected at the several small islands around Honshu, Japan, which consisted mainly of detrital sands, showed the values of boron from 11 to $48 \mathrm{ppm}$, with the average of $23 \pm 10 \mathrm{ppm}$ which is about one-third of $67 \pm 20 \mathrm{ppm}$ in Nanao Bay deposits. The boron contents of these samples have a close relationship to the coastal geology, and the samples collected at the islands where acidic igneous rocks predominate are relatively rich in boron (av. $20 \pm 5 \mathrm{ppm}$ ) but those derived from basic igneous rocks are meager in it (av, 12 $1 \mathrm{ppm}$ ). The deposits obtained at the islands composed mainly of sedimentary rocks except upper paleozoic formations have a comparatively rich boron content, ranging from 25 to $48 \mathrm{ppm}$.
\end{abstract}

\section{Introduction}

In the previous paper (YAMAMOTO, 1968), the contents of major and minor elements in 21 samples of the shallow-water deposits from Nanao Bay were reported.

The present investigation was undertaken to find the abundance of boron in the same samples. Boron, like gallium and lithium, is known as one of environmental descriminators. It is, therefore, of interest to make a research on the relationship between the boron content of Nanao Bay deposits and the contents of major and minor elements, environments of deposition, coastal geology, or the water depth. Further, in order to find out relation of born content to coastal geology, the abundance and distribution of boron in the shallow-water deposits taken at several small islands, which have relatively simple

* Received June 7, 1968

** Faculty of Technology, Kanazawa University geological structure and are influenced little by the geology of remote place were studied. The shallow-water deposits of Kasaoka Bay, Okayama Prefecture and Oki Island, Shimane Prefecture were also analysed.

\section{Analytical methods}

Boron was determined by the methylene bluedichloroethane extraction methods of UTSUMI et al. (1965) and MUTO et al. (1966), as follows.

10 to $15 \mathrm{mg}$ of sample, ground finely and dried to a constant weight, is placed in a platinum crucible. The sample is decomposed on a sand bath by heating with $1-2 \mathrm{ml}$ of $1 \mathrm{M}$ phosphoric acid and $5 \mathrm{ml}$ of $5 \%$ hydrofluoric acid. After complete decomposition, $3 \mathrm{ml}$ of $5 \%$ hydrofluoric acid and $2 \mathrm{~m} l$ of $1 \mathrm{~N}$ sulfuric acid are added to the residue and the solution is diluted to $15 \mathrm{ml}$ with water. The solution, allowed to stand for 30 minutes at the temperature higher than $20^{\circ} \mathrm{C}$, is tranferred to a $100-\mathrm{m} l$ separatory funnel made 
Jour. Oceanogr. Soc. Japan, Vol. 24, No. 5 (1968)

Table 1. Boron content of the shallow-water deposits in Nanao Bay.

\begin{tabular}{c|cccc}
\hline Sample No. & Locality & Type of deposits & $\begin{array}{c}\text { Depth } \\
(\mathrm{m})\end{array}$ & $\begin{array}{c}\text { Boron content* } \\
(\mathrm{ppm})\end{array}$ \\
\hline 1 & West Bay & mud & 5 & 70 \\
2 & West Bay & mud & 9 & 62 \\
3 & West Bay & mud & 7 & 68 \\
4 & West Bay & mud & 11 & 73 \\
5 & West Bay & mud & 10 & 68 \\
$5 \mathrm{P}$ & West Bay & sandy mud & 9 & 16 \\
6 & South Bay & mud & 20 & 96 \\
7 & South Bay & mud & 7 & 103 \\
8 & South Bay & mud & 13 & 91 \\
9 & South Bay & mud & 19 & 87 \\
10 & South Bay & mud & 24 & 78 \\
10 & South Bay & mud & 7 & 86 \\
11 & North Bay & mud & 23 & 58 \\
12 & North Bay & mud & 29 & 46 \\
13 & North Bay & mud & 30 & 64 \\
14 & North Bay & mud & 45 & 75 \\
15 & North Bay & mud & 35 & 61 \\
16 & North Bay & mud & 17 & 64 \\
17 & North Bay & mud & 19 & 49 \\
18 & North Bay & mud & 25 & 32 \\
19 & North Bay & mud & 31 & 54 \\
\hline
\end{tabular}

* In these values, the analytical error is found, at highest, to be $10 \%$.

Table 2. Average boron contents of the deposits of West, South and North Bays of Nanao (summary of Table 1).

\begin{tabular}{l|c|c|c|c}
\hline \multirow{2}{*}{ Deposit of Nanao Bay } & $\begin{array}{c}\text { Number of } \\
\text { samples }\end{array}$ & $\begin{array}{c}\text { Average depth } \\
(\mathrm{m})\end{array}$ & \multicolumn{2}{|c}{ Boron content (ppm) } \\
\cline { 3 - 4 } & 6 & 9 & $16-73$ & Average \\
\hline Deposits of West Bay & 6 & 15 & $78-103$ & $60 \pm 22$ \\
Deposits of South Bay & 9 & 28 & $32-75$ & $90 \pm 9$ \\
Deposits of North Bay & 21 & 19 & $16-103$ & $56 \pm 12$ \\
All the deposits & & & $67 \pm 20$ \\
of Nanao Bay & & & \\
\hline
\end{tabular}

of polyethylene. Boron is then extracted as methylene blue-tetrafluoroborate complex by shaking for 1 minute with $3 \mathrm{ml}$ of $0.001 \mathrm{~mol} / l$ methylene blue and $10 \mathrm{~m} l$ of 1,2 -dichloroethane. After separation of each liquid phase, the lower organic layer is poured into another separatory funnel and washed with water by shaking for 1 minute. The 1,2-dichloroethane phase is then transferred to a $10 \mathrm{~mm}$-cell and its absorbance is measured at $660 \mathrm{~m} \mu$ against a dichloroethane blank.

\section{Results and discussion}

1) The boron content of Nanao Bay deposits In the deposits of Nanao Bay born contents range from 16 to $103 \mathrm{ppm}$ and the average is $67 \pm 20 \mathrm{ppm}$, as is shown in Tables 1 and 2 . Generally, boron is more abundant in the deposits of South Bay rich in sulfur, nitrogen and organic carbon than in those in West and North Bays. 
The average born content of group $S$ (South Bay), $90 \pm 9 \mathrm{ppm}$, is approximately 1.5 times greater than the respective averages of $60 \pm 22$ and $56 \pm 12 \mathrm{ppm}$ in the groups $W$ (West Bay) and $N$ (North Bay). This is probably due to the differences of the sedimentation environments in North, South and West Bays which are classified topographically into semi-open, semiclosed and closed types respectively.

Among these deposits Sample 5P which consisted mainly of detrital sand shows the lowest value of boron, $16 \mathrm{ppm}$, while the highest value, $103 \mathrm{ppm}$, is found in Sample 7, which is derived mostly from nondetrital mud and is comparatively rich in copper and zinc. Generally, no appreciable enrichment of boron occurs in shallow-water deposits consisting of detrital sands, as is shown in Table 4.

The average boron content of the deposits from Nanao Bay, $67 \pm 20 \mathrm{ppm}$, is approximately $2-3$ times greater than the averages of $22 \pm 7,33 \pm 6$, and $23 \pm 10 \mathrm{ppm}$ in the deposits collected at Kasaoka Bay, Oki and several small islands around Honshu, Japan respectively, but is slightly lower than the average boron content of the muds at Paria (HIRST, 1962) $81 \mathrm{ppm}$ and is approximately in the middle between 50 and 93 $\mathrm{g} /$ ton in the deep sea sediments (LANDERGREN, 1948), as is shown in Table 6.

HARDER (1959) stated that the boron content of the clay sediments is dependent on the mineral assemblage of the sediment, the grain size, and other conditions. As to adsorption of boron on clay minerals HosoKAWA (1962) stated that little plays an important part and boron is fixed into crystal structure (FREDICKSON et al., 1960).

In fact, boron is more abundant in the deposits of Nanao Bay rich in clay minerals than in those of detrital sands obtained at small islands. This is probably due to the adsorption of boron by clay minerals such as illite, montmorillonite and kaolinite, whose presence are confirmed by $X$-ray diffraction method.

As to the relation of boron to other elements, there are positive correlations between the dontents of boron and those of sulfur, organic carbon and nitrogen, as is shown in Figs. 1, 2 and 3. It can be also found that boron and vanadium are in close relationship, as Fig. 4

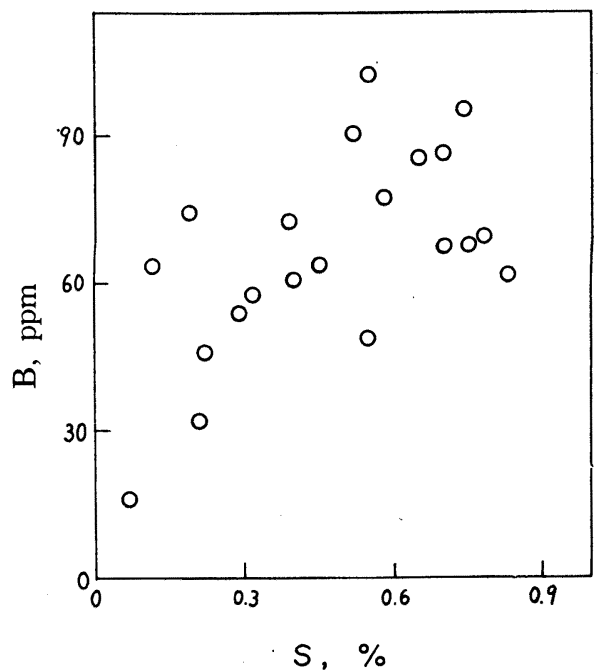

Fig. 1. Relationship between the contents of boron and sulfur in deposits of Nanao Bay.

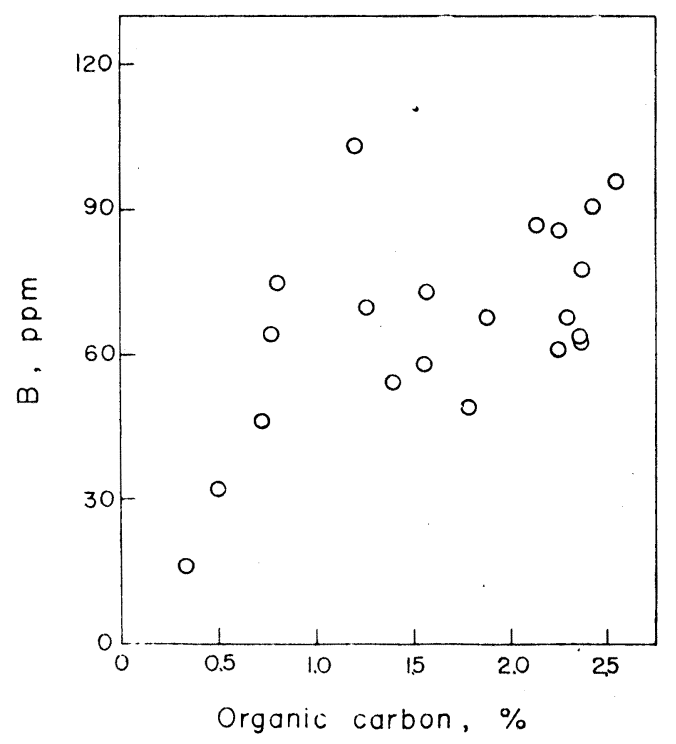

Fig. 2. Relationship between the contents of boron and organic carbon in deposits of Nanao Bay.

shows. Sulfur, organic carbon, nitrogen and vanadium which are closely related to boron have a close correlation with organic matter, derived from a part of marine organisms which adsorbed concentrated boron from sea water.

2) The boron contents of the shallow-water deposits from Kasaoka Bay and Oki Island

In order to find the relation between the boron 


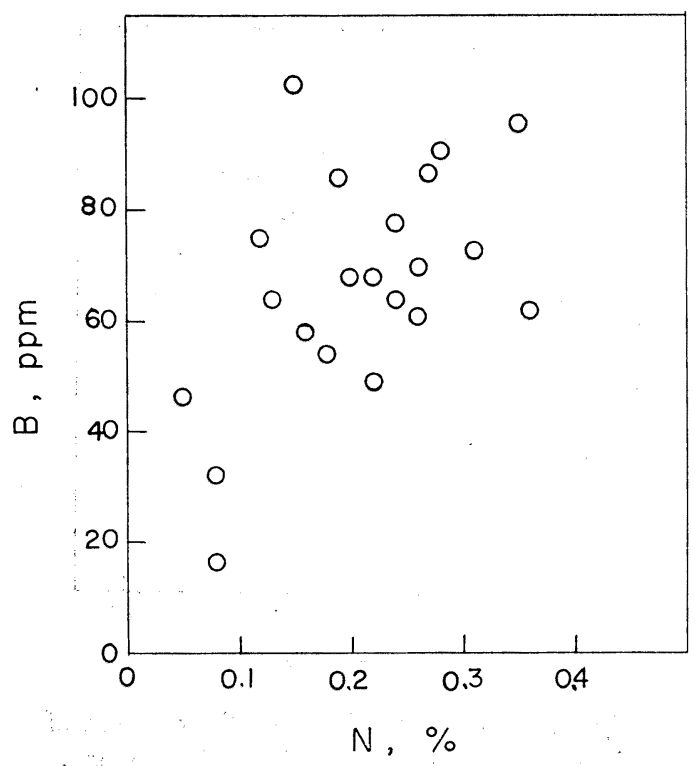

Fig. 3. Relationship between the contents of boron and nitrogen in deposits of Nanao Bay.

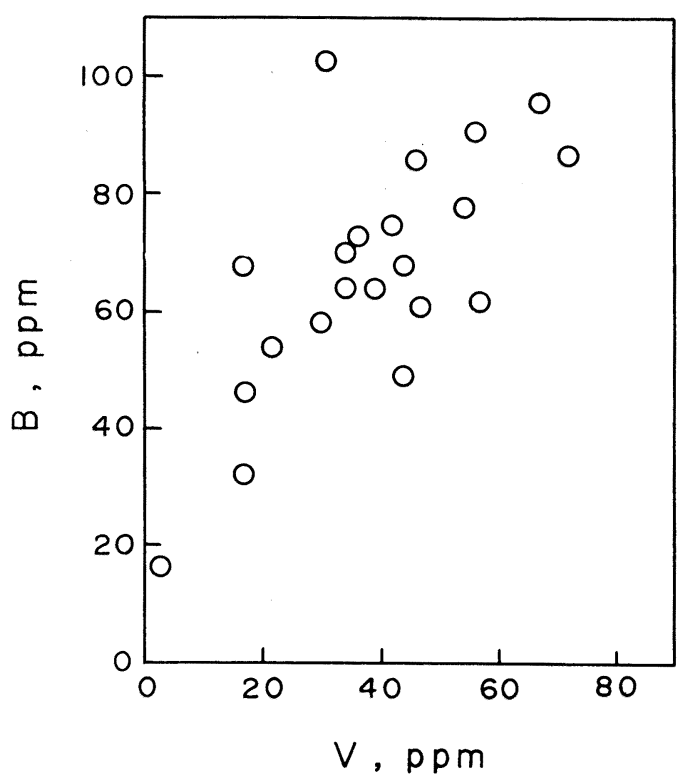

Fig. 4. Relationship between the contents of boron and vanadium in deposits of Nanao Bay.

Table 4. Boron contents of the shallow-water

\begin{tabular}{|c|c|c|}
\hline Locality & Geology** & Type of deposits \\
\hline $\begin{array}{l}\text { Hiroshima, Kagawa-ken } \\
\text { Nakashima, Ehime-ken } \\
\text { Ogishima, Kagawa-ken } \\
\text { Momoshima, Hiroshima-ken } \\
\text { Yokoshima, Hiroshima-ken } \\
\text { Okinoshima, Kōchi-ken } \\
\text { Kogoshima, Ehime-ken } \\
\text { Kōnoshima, Okayama-ken } \\
\text { Tashima, Hiroshima-ken } \\
\vdots \\
\text { Heigunshima, Yamaguchi-ken } \\
\text { Kajishima, Ehime-ken } \\
\text { Kasatoshima, Yamaguchi-ken } \\
\bar{O}_{\text {tsushima, Yamaguchi-ken }} \\
\text { Takashima, Ōita-ken } \\
\text { Nushima, Hyōgo-ken } \\
\text { Shishishima, Kagawa-ken } \\
\text { Mutsukishima, Ehime-ken } \\
\bar{O}_{\text {nyūshima, Ōita-ken }} \\
\text { Shimoniizu-mura, Ōita-ken } \\
\text { Sugari, Owashishi, Mieken } \\
\text { Tobishima, Yamagata-ken } \\
\text { Higashitonda-mura Wakayama-ken } \\
\text { Himagashima, Aichi-ken } \\
\end{array}$ & 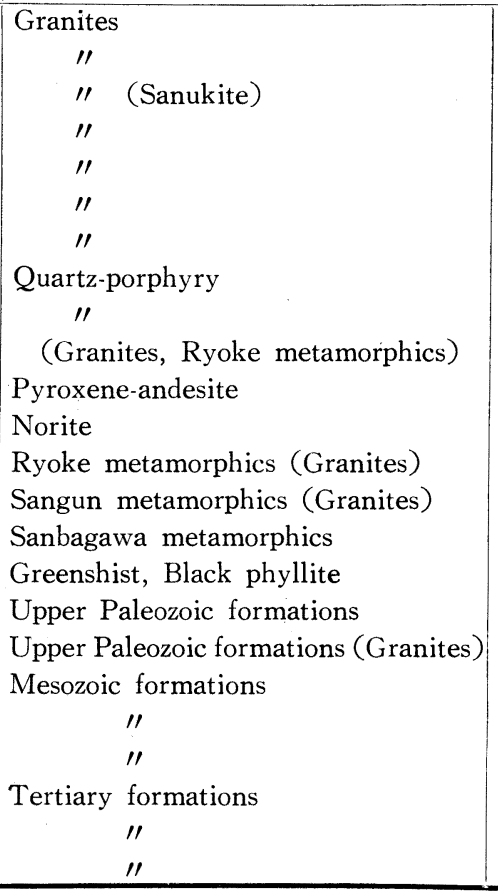 & $\begin{array}{l}\text { grayish white sand } \\
\text { light brown sand } \\
\text { "I } \\
\text { grayish brown sand } \\
\text { brown sand } \\
\text { light brown sand } \\
\text { greenish sandy mud } \\
\text { grayish brown sand } \\
\text { light blackish gray sand } \\
\text { grayish brown sandy mud } \\
\text { blackish green sand } \\
\text { grayish blue sand } \\
\text { grapish white sand } \\
\text { light brown sand } \\
\text { yellowish brown sand } \\
\text { brown sand } \\
\text { " } \\
\text { blackish gray sand } \\
\text { " } \\
\text { [ight blackish gray sand } \\
\text { light grayish brown sand }\end{array}$ \\
\hline
\end{tabular}

Himagashima, Aichi-ken

* Three capes are also included.

- ** Only the predominant rocks and formations are shown. The parentheses are for the rocks which

*** The experiments were carried out within $10 \%$ of error in the case of boron, and within $2 \%$ of error 
Table 3. Boron content in the deposits of Kasaoka Bay and Oki.

\begin{tabular}{|c|c|c|c|}
\hline \multicolumn{4}{|c|}{ Kasaoka Bay, Okayama Prefecture } \\
\hline Depth (m) & Number of samples & Type of deposits & B content $(\mathrm{ppm})$ \\
\hline $1.7-3.4$ & 3 & mud & 16 \\
\hline $9.2-13.1$ & 2 & mud & 27 \\
\hline $15.8-17.3$ & 3 & mud & 17 \\
\hline 39 & 1 & mud & 29 \\
\hline \multicolumn{4}{|c|}{ Oki, Shimane Prefecture } \\
\hline Depth (m) & Number of samples & Type of deposits & B content $(\mathrm{ppm})$ \\
\hline 8.3 & 1 & mud & 28 \\
\hline 11.8 & 1 & mud & 29 \\
\hline 27 & 1 & mud & 36 \\
\hline 41 & 1 & mud & 40 \\
\hline
\end{tabular}

deposits collected from various small island*.

\begin{tabular}{|c|c|c|c|c|c|c|c|c|}
\hline $\begin{array}{l}\text { Composits } \\
\text { of }\end{array}$ & $\begin{array}{l}B^{* * *} \\
\text { ppm }\end{array}$ & $\begin{array}{c}\mathrm{SiO}_{2}{ }^{* * * *} \\
\%\end{array}$ & $\begin{array}{c}\mathrm{Fe}_{2} \mathrm{O}_{3}{ }^{* * *} \\
\end{array}$ & $\begin{array}{c}\mathrm{Al}_{2} \mathrm{O}_{3} * * * \\
\%\end{array}$ & $\underset{\%}{\mathrm{MnO}_{\%}^{* * *}}$ & $\underset{\%}{\mathrm{CaO}_{\% * * *}^{* *}}$ & $\underset{\%}{\mathrm{MgO}^{* * *}}$ & $\begin{array}{c}\mathrm{CO}_{2} * * * \\
\%\end{array}$ \\
\hline 5 deposits & 17 & 82.92 & 0.56 & 9.23 & trace & 0.74 & 0.33 & - \\
\hline $5 \quad 1$ & 15 & 79.28 & 1. 26 & 11.01 & 0.01 & 1.09 & 0.34 & - \\
\hline $5 \prime \prime$ & 17 & 77.49 & 1.97 & 12.16 & 0.03 & 2.23 & 0.24 & - \\
\hline $4 \prime \prime$ & 16 & 75.81 & 2.34 & 12.21 & 0.04 & 1.69 & 0.40 & - \\
\hline $5 \quad \prime \prime$ & 16 & 76.21 & 2.49 & 14.77 & 0.03 & 1. 32 & 0.25 & - \\
\hline$\prime \prime$ & 26 & 73.96 & 3.08 & 10.40 & 0.04 & 3.76 & 0.46 & 2.33 \\
\hline "I & 17 & 70.62 & 4. 28 & 12.98 & 0.11 & 2.85 & 1.14 & 1.66 \\
\hline $5 \prime \prime$ & 27 & 79.24 & 1.56 & 9.74 & 0.02 & 2.57 & 0.56 & 1. 28 \\
\hline$\prime \prime$ & 25 & 75.87 & 2.02 & 11.52 & 0.03 & 0.90 & 0.49 & - \\
\hline$\prime \prime$ & 13 & 71.20 & 2.98 & 13.49 & 0.04 & 2.92 & 1.87 & - \\
\hline$\prime \prime$ & 11 & 52.64 & 8.25 & 20.06 & 0.18 & 9. 69 & 4.58 & 0.52 \\
\hline$\prime \prime$ & 18 & 79. 36 & 3.05 & 6.82 & 0.11 & 2.82 & 1.12 & 1.58 \\
\hline$\prime \prime$ & 15 & 47.48 & 6.14 & 12.31 & 0.12 & 15.95 & 2.74 & 8. 28 \\
\hline$\prime \prime$ & 22 & 70.02 & 2.87 & 9.51 & 0.06 & 7.05 & 1.86 & 4. 01 \\
\hline$\prime \prime$ & 27 & 74. 26 & 2.16 & 7.07 & 0.06 & 5.62 & 0.74 & 3.86 \\
\hline$\prime \prime$ & 18 & 87.54 & 1.00 & 5.77 & 0.04 & 1. 19 & 0.21 & - \\
\hline$\prime \prime$ & 16 & 79. 25 & 1.02 & 10.05 & 0.01 & 2. 13 & 0.52 & - \\
\hline$\prime \prime$ & 35 & 76.42 & 2.99 & 10.95 & 0.03 & 1.80 & 0.26 & 0.50 \\
\hline$\prime \prime$ & 44 & 70.67 & 5. 21 & 13.37 & 0.08 & 0.76 & 1.10 & - \\
\hline$\prime \prime$ & 48 & 72.20 & 3. 38 & 11. 27 & 0.04 & 3.45 & 0.65 & 1. 20 \\
\hline$\prime \prime$ & 25 & 57.69 & 3.69 & 14.82 & 0.05 & 8.56 & 2. 20 & 5.14 \\
\hline$\prime \prime$ & 29 & 56.25 & 2.76 & 7.15 & 0.01 & 15. 27 & 1. 25 & 11. 28 \\
\hline 11 & 28 & 77.54 & 1.79 & 8.77 & 0.01 & 3.83 & 0.51 & 2.18 \\
\hline
\end{tabular}

distribute in land areas relatively far from the location sampled. in other elements. 
Table 5. Boron content and the geology. (summary of Table 3)

\begin{tabular}{l|c|c|c}
\hline \multirow{2}{*}{ Geology } & $\begin{array}{c}\text { Number } \\
\text { of } \\
\text { samples }\end{array}$ & \multicolumn{2}{|c}{ B content (ppm) } \\
\cline { 3 - 4 } & & Range & Average \\
\hline Igneous rocks & 9 & $15-27$ & $20 \pm 5$ \\
Acidic rocks & 2 & $11-13$ & $12 \pm 1$ \\
Basic rocks & & - & 18 \\
Metamorphic rocks & 1 & - & $21 \pm 6$ \\
Gneisses & 3 & $15-27$ & \\
Crystalline schist & & & \\
Sedimetary rocks & & $16-18$ & $17 \pm 1$ \\
Upper Paleozoic & 2 & $35-48$ & $42 \pm 7$ \\
formations & 3 & $25-29$ & $27 \pm 2$ \\
Mesozoic formations & 3 & \\
Tertiary formations & 3 & $25-29$
\end{tabular}

content and the depth, the deposits in Kasaoka Bay, Okayama Prefecture, and at Oki Islands, Shimane Prefecture, were analysed. Table 3 shows the analytical results obtained in these samples. No systematic variation of boron contents with respect to the depth was found in the deposits Kasaoka Bay and Oki, although boron has a tendency to increase to some extent with depth in the latter. Therefore, it seems necessary to analyses a much larger number of deposits taken at various depths at many more places to find such relations.

3) The boron content of the shallow-water deposits collected at several small islands around Honshu, Japan

The analytical results are presented in Table 4 and summarized in Table 5, and these figures are given on the sea-salt-free and dry basis.

The boron contents of $11-48 \mathrm{ppm}$ and the average of $23 \pm 10 \mathrm{ppm}$ are found in these deposits derived mainly from detritus which is approximately one-third of $67 \pm 20 \mathrm{ppm}$, the average of Nanao Bay deposits. It is probably that a considerable variation in boron contents of these deposits is attributed to the difference in geology of the land adjacent to the location of sampling. As is shown in Tables 4 and 5, the average boron content of $20 \pm 5 \mathrm{ppm}$ in the deposits of Hiroshima-Tashima where igneous acidic rocks predominate, is approximately two times greater than the average of $12 \pm 1 \mathrm{ppm}$ in the deposits of Heigunshima and Kajishima where igneous basic rocks are predominant. Such a variation in boron content in these deposits agrees well with the tendency that boron content is higher in igneous acidic rocks, such as 15 and $20 \mathrm{ppm}$ reported by SAHAMA (1945) and WASSERSTEIN (1951) respectively, than that in igneous basic rocks, which is 9 (SAHAMA, 1945) and $10 \mathrm{ppm}$ (VINOGSADOV, 1956). It is one of interest that the values of boron contents of igneous rocks are close to the values of $20 \pm 5$ and $12 \pm 1 \mathrm{ppm}$ in the deposits described above, suggesting that the deposits is derived mainly from igneous rocks.

Boron, generally, is contained more abundantly in sedimentary rocks than in igneous rocks. SAITO (1965) stated that the average boron content in sedimentary rocks is $85 \mathrm{ppm}$, which is approximately eight times the value in igneous acidic rocks. A similar tendency can be expected to occur in these deposits, too. Actually, the

Table 6. Average boron for shallow-water deposits from Nanao Bay, Kasaoka Bay and various small islands and comparison with boron figures derived by other workers.

21 Muds from the Nanao Bay (This work) B(ppm) 4 Muds from Kasaoka Bay (This work) $22 \pm 7$

4 Muds from Oki, Shimane Prefecture $\quad 33 \pm 6$ (This work)

23 Sands from various small islands around Japan Proper (This work)

6 Greenish muds from Gulf of Paria (HIRst, 1962)

3 Delta sands from Gulf of Paria (HIRst, 1962)

14 Modern marine argillaceous sediments (POTTER et al., 1962)

19 Modern fresh-water argillaceous sediments 45.6 (PotTER et al., 1962)

22 Deep-sea sediment from the Pacific (GOLDBERG and ARRHENIUS, 1958)

25 Silurian shales (SPENCER, 1957)

Recent marine clays (GoLDSCHMIDT and Peters, 1923d)

Marine hpdrolyzates (LANDERGREN, 1945) 150

Bottom sediment, Tyrrhenian Sea

(LANDERGREN, 1948)

Volcanic rocks (HARIER, 1959) 
boron contents of the deposits of ShishishimaHimagashima composed mainly of sedimentary rocks are higher than those of other islands formed predominantly by igneous rocks, especially high in the deposits in mesozoic formations showing the average of $42 \pm 7 \mathrm{ppm}$. This is probably due to the shales rich in boron, which are characteristic of the mesozoic formations and considered to be deposited in rather deep sea.

\section{Summary}

From the above results and discussions the following conclusions were derived: 1) The boron contents of Nanao Bay deposits are affected considerably by the sedimentary environments and the amounts of clay minerals such as illite, montmorillonite and kaolinite; 2) No clear relationship of boron content to depth is found in the deposits from Kasaoka Bay and Oki Island; 3) the average boron content of the deposits from Hiroshima-Tashima, where igneous acidic rocks are predominant, is approximately 2 times higher than that of the deposits from Heigunshima and Kajishima, where igneous basic rocks predominate; 4) boron is more abundant in the deposits derived from sedimentary rocks, particularly mesozoic formations, than in those from igneous and metamorphic rocks.

\section{Acknowledgements}

The author wishes to express his sincere thanks to Dr. Masayoshi IsHibASHI, Ex-President of the Kanazawa University, for his kind encourgement. Thanks are also due to Professors Shunzo UEDA and Yoshio KASENO of the Kanazawa University for their valuable advice throughout this study.

\section{References}

Fredrickson, A. F. and R. C. Reynolds (1960): How measuring Paleosalinity aids exploration.
Oil and Gas, Jour, 58, No. 5, 154, G. S. A. 2 1287.

HARDER, H. (1959): Beitrag zur Geochemie des Bors II. Bor in Sedimenten. Nachr. Akad. Wiss Gottingen. Math.-Phys. K1. No. 6, 123.

Hirst, D. M. (1962): The geochemistry of modern sediments from the Gulf of Paria-II. The loca: tion and distribution of trace elements. Geochim. Cosmochim. Acta, 26, 1147-1187.

HosokawA, I. (1962): A review of chemical studies on marine sediments (chiefly on shallowwater deposits). Jour. Oceanogr. Soc. Japan, 20th Anniversary Vol., 541-562. (In Japanese)

LANDERGREN, S. (1948): On the geochemistry of Swedish iron ores and associated rocks. A study on iron are formation. Sveriges Geol. Undersökn. Ser C, No. 496, 1-182.

Muto, S. and H. Murayama (1966): On the boron content of sedimentary rocks. presented at the Symposium on Geochemistry, Kanazawa, October, $191-192$.

SAITO, K. (1965): “MUKIKAGAKU ZENSHO”, $\mathrm{X}-2, \mathrm{~B}, \mathrm{C}, \mathrm{Ge}$, Maruzen Co., Ltd., Tokyo, Japan, $11-25$ pp. (In Japanese)

SAHAMA, T. G. (1945): Trace elements in the rocks of southern Finish Lapland. Bull. comm. geol. Finlande No. 135, 5-86.

UTSUMI, S., S. ITO and A. IsOzAKI (1965): Spectrophotometric determination of ultramicro amounts of boron by a solvent extraction method. Nippon Kagaku Zasshi (J. Chem. Soc. Japan, Pure Chem. Sect.), 86, 921-925. (In Japanese)

Vinogradov, A. P. (1951): Geochemistry, No. 143.

WAsserstein, B. (1951): South African granites and their boron content. Geochim. Cosmochim. Acta, 1, 329-338.

YАMAмото, Y. (1968): The chemical composition of shallow-water deposits of Nanao Bay, Japan. Jour. Oceanogr. Soc. Japan, 24(3), 94-102. YAmamoto, Y. (1968): Minor elements in shallow-water deposits from Nanao Bay, Japan. Ibid. 24(4), 160-166. 


\section{浅海底土のホウ素含量}

山本善 一

要旨 石川県七尾湾の浅海底土のホウ素含量をしらべ, 更にホウ素含量と水深ならびに沿岸の地質との関倸をみ るために, 岡山県笠岡湾, 島根県鿵岐ならびに本州周辺 の各種の島嬹から採取した浅海堆積物を分析した。

七尾湾海底土のホウ素含量は 16 103 ppm の範囲にわ たり,その平均值は $67 \pm 20 \mathrm{ppm}$ であった. 外洋の影響 を受けやすい七尾湾北湾の海底土のホウ素含量 (平均値 $56 \pm 12 \mathrm{ppm} ）$ は，比較的その影響の少ない七尾湾南湾の もの（平均值 $90 \pm 9 \mathrm{ppm}$ ）よりかなり低い.これらの浅 海底土の木ウ素含量は有機物含量の増大と共に増加す る. ホウ素含量とイオウ, 有機炭素, 窒素およびバナジ ウム含量との間には正の相関関係が存在する.

笠岡湾および隠岐から採取した試料のホウ素含量はそ
れぞれ $16 \sim 29$ および $28 \sim 40 \mathrm{ppm}$ の範囲にわたるが, この結果だけでは水深との相関は明瞭でない.

本州周辺の比較的均一な地質から成る小さな島嵲（23 か所）から採取した. 主に砕屑岩源の砂よりなる浅海堆 積物のホウ素含量は $11 \sim 48 \mathrm{ppm}$ で, 平均 $23 \pm 10 \mathrm{ppm}$ である. これは上述の七尾湾海底土の平均値 $67 \pm 20 \mathrm{ppm}$ のほぼ $1 / 3$ である. また, これらの試料のホウ素含量は 沿岸の地質と関連が哚く, 酸性火成岩類の主に分布して いる島から採取した試料には比較的ホウ素が多く（平均 值 $20 \pm 5 \mathrm{ppm}$ ), 塩基性火成岩に由来する試料には少な い(平均値 $12 \pm 1 \mathrm{ppm}$ ). これに対して, 上部古生界を 除く主に堆積岩よりなる島から採取した試料は $25 \sim 48$ ppm にわたる, 比較的高いホウ素含量を示す. 